\title{
Kekerabatan Kosa Kata Bahasa Karo, Bahasa Nias, dan Bahasa Simalungun di Kota Medan: Kajian Linguistik Historis Komparatif
}

\author{
Sherly Novita \\ email: sherly.novita.1991@gmail.com \\ Program Magister Linguistik, Universitas Sumatera Utara, Indonesia \\ Dwi Widayati \\ email: dwiwidayati@usu.ac.id \\ Program Magister Linguistik, Universitas Sumatera Utara, Indonesia
}

\begin{abstract}
Abstrak
Artikel ini berjudul "Kekerabatan Kosa Kata Bahasa Karo, Bahasa Nias, dan Bahasa Simalungun di Kota Medan: Kajian Linguistik Historis Komparatif'. Hasil penelitian menunjukkan bahwa terjadi hubungan kekerabatan antara ketiga bahasa tersebut. Terdapat 42 pasangan kata yang berkerabat antara Bahasa Karo (BK) dengan Bahasa Nias (BN), yaitu sebesar 21\%; terdapat 73 pasangan kata yang berkerabat antara Bahasa Karo (BK) dengan Bahasa Simalungun (BS), yaitu sebesar 37\%; terdapat 47 pasangan kata yang berkerabat antara Bahasa Nias (BN) dengan Bahasa Simalungun (BS), yaitu sebesar 24\%. Dari jumlah persentase kekerabatan tersebut dikelompokkan bahwa BK dan BN adalah keluarga bahasa. Selanjutnya, dihitung waktu pisah kedua bahasa yang dibandingkan melalui rumusan $\mathrm{W}=\log \mathrm{C} / 2$ $\log$ r. Hasilnya adalah 3,597. Artinya BK dan BN adalah bahasa yang berkerabat dan merupakan satu bahasa yang sama sekitar 3,597 tahun yang lalu atau sekitar tahun 1,578 Sebelum Masehi (dihitung dari tahun 2019) dan termasuk dalam tingkat bahasa serumpun (family of stock). BK dan BS adalah bahasa kerabat dan merupakan satu bahasa yang sama sekitar 2,290 tahun yang lalu atau sekitar tahun 271 SM (dihitung dari tahun 2019), sebelum akhirnya berpisah dan termasuk dalam tingkat bahasa sekeluarga (language of family). Lalu BN dan BS adalah Bahasa yang berkerabat dan berpisah sekitar 3,288 tahun yang lalu atau sekitar tahun 1,269 SM (dihitung dari tahun 2019), dan termasuk dalam tingkat bahasa serumpun (family of stock).
\end{abstract}

Kata Kunci: kekerabatan, Karo, Nias, Simalungun, leksikostatistik 
Vol. 26. No. 2

\begin{abstract}
This article is entitled "The Kosa Relationship of the Word Karo Language, Nias Language, and Simalungun Language in Medan City: Comparative Historical Linguistic Study". The research method used is a qualitative method. The methods and data collection techniques used are the method of referring to tapping, skillful, and recording techniques. The data analysis methods and techniques used are qualitative and quantitative methods with lexicostatistics techniques. In lexicostatistics, language kinship is seen based on the sound equations in the lexicon that appear in these languages. This phonetic resemblance will be the basis of whether a word in one language has a relationship with another language. The indicator used to determine the word kinship is a basic vocabulary called the basic Swadesh vocabulary which amounts to 200 vocabulary which is considered to exist in all languages in the world. The results of the study indicate that there was a kinship between the three languages. There are 42 related pairs of words between Karo Language (BK) in Nias Language (BN), which is equal to 21\%; there are 73 related pairs of words between Karo Language (BK) and Simalungun (BS) Language, which is 37\%; there are 47 pairs of words related to Nias Language (BN) with Simalungun Language (BS), which is equal to $24 \%$. From the total percentage of kinship grouped, $\mathrm{BK}$ and $\mathrm{BN}$ are language families. Furthermore, the split time of the two languages is calculated compared to the formula $\mathrm{W}=\log \mathrm{C} / 2 \log \mathrm{r}$. The result is 3.597. This means that $\mathrm{BK}$ and $\mathrm{BN}$ are related languages and are one of the same languages around 3,597 years ago or around 1,578 BC (calculated from 2019) and included in the family of stock level. BK and BS are relatives' languages and are the same language about 2,290 years ago or around 271 BC (calculated from 2019), before finally separating and included in the language of family level. Then the BN and BS are related languages and split around 3,288 years ago or around 1,269 BC (calculated from 2019), and included in the family of stock level.
\end{abstract}

Keywords: kinship, Karo, Nias, Simalungun, lexicostatistics 


\section{Pendahuluan}

Bahasa pada dasarnya adalah media yang digunakan manusia untuk berinteraksi satu dengan yang lain. Bahasa dapat berupa lisan maupun tulisan. Bahasa Indonesia memiliki kedudukan istimewa sebagai bahasa nasional dan bahasa negara. Adapun kedudukan bahasa Indonesia dengan bahasa daerah sangat berhubungan, yaitu bahasa daerah sebagai pendukung bahasa nasional.

Penelitian ini membahas kekerabatan dari tiga bahasa yang berbeda. Bahasa yang diangkat dalam penelitian ini adalah bahasa Karo, Nias, serta bahasa Simalungun di kota Medan. Medan adalah ibukota provinsi Sumatra Utara, Indonesia. Kota ini merupakan kota multicultural yang terdiri atas berbagai macam etnis dengan beragam bahasa daerah. Adapun bahasa daerah di negara Indonesia memiliki kemiripan dalam pengucapan beberapa kosa katanya. Kemiripan antar bahasa daerah dapat terjadi karena adanya kekerabatan bahasa.

Kekerabatan dalam istilah linguistik diartikan sebagai hubungan antara dua bahasa atau lebih yang diturunkan dari sumber yang sama (KBBI, 2018). Sedangkan, bahasa berkerabat diartikan sebagai bahasa yang mempunyai hubungan genealogis dengan bahasa lain. Dengan demikian, bahasa yang berkerabat adalah bahasa yang memiliki hubungan antara yang satu dengan yang lainnya. Hubungan ini bisa jadi merupakan asal dari induk yang sama sehingga terdapat kemiripan, atau dapat juga karena adanya ciri-ciri umum yang sama. Dalam hal bahasa, kemiripan ini terutama terlihat dari segi fonologinya, atau mungkin morfologi, bahkan sintaksisnya. Kridalaksana (2008:116) menjelaskan dalam Kamus Linguistik bahwa Kekerabatan (genetic relationship) adalah hubungan antara dua bahasa atau lebih yang diturunkan dari sumber bahasa induk yang sama, yang disebut bahasa purba (proto-Austronesia).

\section{Tinjauan Pustaka}

Terdapat tiga tulisan yang digunakan sebagai acuan atau tinjauan pustaka dalam makalah ini yaitu Dwi Widayati (2018) yang berjudul "Hubungan Kekerabatan Bahasa Nias dan Bahasa Sigulai" yang juga menganalisis bahasa Nias sebagai objek kajian dengan menggunakan 200 kosa kata dasar Swadesh dan dibandingkan dengan bahasa Sigulai melalui perbandingan pasangan identik, berbeda vokal, berbeda konsonan, berbeda satu silabel, dan berbeda satu vokal, dan berbeda satu konsonan.

Tulisan lain yang terkait dalam kajian Linguistik Historis Komparatif ditemukan dalam tesis Juliana (2012) yang berjudul "Kekerabatan Bahasa Batak, Bahasa Nias, dan Bahasa Melayu" dengan menggunakan teknik leksikostatistik. Menurut Juliana, perbandingan antara BB dengan $\mathrm{BN}$ menghasilkan jumlah kata berkerabat adalah 65 kosa kata atau 33\%. Kedua bahasa berada pada tingkat rumpun atau stock; perbandingan antara BB dengan BM menghasilkan Jumlah kata berkerabat adalah 83 kosa kata atau $42 \%$. Kedua bahasa berada pada tingkat keluarga atau family: perbandingan antara BN dengan BM menghasilkan jumlah kata berkerabat adalah 62 kosa kata atau 31\%. Kedua bahasa berada pada tingkat satu rumpun atau stock.

Berikutnya merupakan artikel Juliana (2013) yang berjudul "Tingkat Kekerabatan Bahasa Mandailing, Bahasa Jawa, dan Bahasa Aceh" yang menyimpulkan bahwa tingkat kekerabatan BM dan BJ adalah 32,5\% dan berada dalam satu rumpun atau stock; tingkat kekerabatan BJ dan BA adalah 25,5\% dan berada dalam satu rumpun atau stock; dan tingkat kekerabatan BA dan BM adalah 36\% dan berada dalam satu keluarga atau family.

\section{Landasan Teori}

Penelitian ini berbasis pada teori dalam Linguistik Bandingan Historis (Linguistik Historis Komparatif). Salah satu tujuan dalam Linguistik Historis Komparatif ialah mempersoalkan bahasa-bahasa yang serumpun dengan mengadakan perbandingan mengenai unsur-unsur yang menunjukkan kekerabatannya (Crowley, 1987; Keraf, 1991). Dalam penelitian 
ini, aspek bahasa yang dijadikan dasar dalam perbandingan fonologi. Penghitungan kekerabatan bah Keraf (1984:22) mengatakan bahwa linguistik bandingan historis (linguistik historis komparatif) adalah suatu cabang dari Ilmu Bahasa yang mempersoalkan bahasa dalam bidang waktu serta perubahan-perubahan unsur bahasa yang terjadi dalam bidang waktu tersebut. Adapun salah satu tujuan dan kepentingan linguistik historis komparatif adalah mengadakan pengelompokkan (sub-grouping) bahasa-bahasa dalam suatu rumpun bahasa. Bahasa-bahasa dalam suatu rumpun yang sama belum tentu sama tingkat kekerabatannya atau sama tingkat kemiripannya satu sama lain.

Keraf (1984:34) mengatakan bahwa bahasabahasa kerabat yang berasal dari proto yang sama selalu akan memperlihatkan kesamaan-kesamaan berikut:

1. kesamaan sistem bunyi (fonetik) dan susunan bunyi (fonologis);

2. kesamaan morfologis, yaitu kesamaan dalam bentuk kata dan kesamaan dalam bentuk gramatikal;

3. kesamaan sintaksis, yaitu kesamaan relasinya antara kata-kata dalam sebuah kalimat.

Dalam membandingkan dua bahasa atau lebih dapat menggunakan teknik leksikostatistik. Keraf (1984:121) mengatakan bahwa leksikostatistik adalah suatu teknik dalam pengelompokan bahasa yang lebih cenderung mengutamakan peneropongan kata-kata (leksikon) secara statistik, untuk kemudian berusaha menetapkan pengelompokkan itu berdasarkan persentase kesamaan dan perbedaan suatu bahasa dengan bahasa lain.

Keraf (1984:128) menyatakan bahwa sebuah pasangan kata akan dinyatakan kerabat bila memenuhi salah satu ketentuan (a) pasangan itu identik, (b) pasangan itu memiliki korespondensi fonemis, (c) kemiripan secara fonetis, atau (d) satu fonem berbeda.

Setelah menetapkan kata-kata kerabat dengan prosedur seperti yang dikemukakan di atas, maka dapat ditetapkan besarnya persentase dari kedua bahasa yang dibandingkan. Kemudian jika sudah didapatkan persentase kekerabatan tersebut, dapat dihitung waktu pisah kedua bahasa yang dibandingkan dari bahasa proto yang sama dengan menggunakan rumus:

\section{Keterangan:}

$w=$ waktu pisah dalam ribuan tahun yang lalu $\mathrm{r}=$ retensi atau prosentase konstan dalam 1000 tahun, atau juga disebut indeks, dalam hal ini retensi yaitu $80,5 \%$

$\log =$ logaritma dari $\log$, dapat dicari dengan menggunakan tabel logaritma atau menggunakan kalkulator. Namun lebih efektif jika menggunakan kalkulator.

$\mathrm{C}=$ persentase kerabat

$2=$ pembagi waktu pisah dari kedua bahasa

Hasil dari menghitung waktu pisah dengan menggunakan cara di atas belum menunjukkan kepastian mengenai waktu pisah kedua bahasa. Keraf (1984:132) mengatakan bahwa untuk menghitung jangka kesalahan biasanya dipergunakan kesalahan standar, yaitu $70 \%$ dari kebenaran yang diperkirakan. Kesalahan standar diperhitungkan dengan rumus: $\sqrt{ }$

Keterangan:

$\mathrm{S}=$ kesalahan standar dalam persentase kata kerabat

$\mathrm{C}=$ persentase kata kerabat

$\mathrm{n}=$ jumlah kata yang diperbandingkan (baik kerabat maupun non kerabat atau kata yang memiliki pasangan)

\section{Metode Dan Teknik}

Perbandingan yang sistematis memerlukan metode yang tepat. Penelitian ini menggunakan metode perbandingan untuk menyusun perangkat ciri yang berkorespondensi dalam $\mathrm{BK}, \mathrm{BN}$, dan BS dengan menggunakan daftar kosakata dasar dari ketiga bahasa itu, yang disusun oleh Morris Swadesh. Daftar kosakata itu membawa keuntungan dalam penelitian karena terdiri atas kata-kata nonkultural serta retensi kata dasarnya 
telah diuji dalam bahasa-bahasa yang memiliki naskah-naskah tertulis.

Dalam penetapan kekerabatan kata pada BK, BN, dan BS ditempuh beberapa prosedur berikut. Pertama, dalam daftar kosakata dasar tidak diperhitungkan (i) kata-kata kosong, yaitu glos yang tidak ada katanya, (ii) kata-kata pinjaman, dan (iii) kata-kata kompleks. Kedua, morfem terikat dipisahkan dari kata dasarnya. Maksudnya, bila kata-kata yang dikumpulkan mengandung morfem terikat, morfem itu dipisahkan lebih dahulu agar lebih mudah dalam menetapkan pasangan kata yang sama atau tidak. Ketiga, pasangan kata yang tergolong kerabat memenuhi salah satu ketentuan berikut: (i) pasangan itu identik, yaitu semua fonemnya sama betul; (ii) pasangan itu berkorespondensi secara fonemis; (iii) pasangan itu mirip secara fonetis, yaitu mempunyai posisi artikulatoris yang sama; dan (iv) pasangan itu mempunyai satu fonem yang berbeda karena pengaruh lingkungan yang dimasukinya. Setelah penetapan kata-kata kerabat dengan prosedur di atas, persentase kekerabatan pada kedua bahasa dihitung. Perhitungan ini mengacu pada jumlah pasangan yang sisa, yaitu 200 kata dikurangi dengan kata atau glos yang tidak diperhitungkan karena kosong, pinjaman, dan sebagainya. Pasangan yang sisa terdiri atas kata-kata yang berkerabat dan kata-kata nonkerabat.

\section{Hasil Penelitian dan Pembahasan}

Setelah menguji beberapa bahasa dengan asumsi dasar ketiga ini, hasilnya akan menunjukan bahwa dalam tiap 1000 tahun, kosa kata dasar suatu bahasa bertahan dengan angkaangka rata-rata $80,5 \%$. Apabila kita ingin menghitung retensi (ketahanan) kosa kata dasar kedua bahasa dengan mempergunakan asumsi dengan rumus : $80.5 \% \times \mathrm{N}$. $\mathrm{N}$ adalah jumlah kosa kata dasar yang ada pada awal kelipatan 1000 tahun kedua bahasa. Sehingga, dari 200 kosakata dasar $(\mathrm{N})$ suatu bahasa, sesudah 1000 tahun pertama akan tinggal $80,5 \%$ × $200=161$ kata, sesudah 1000 tahun kedua akan tinggal 80,5\% $\mathrm{x} 161$ kata $=139,6$ kata atau dibulatkan menjadi 140 kata. Selanjutnya sesudah 1000 tahun ketiga kosa kata dasar yang tinggal adalah $80,5 \%$ x 140 kata $=112,7$ kata atau dibulatkan menjadi 113 kata, dan seterusnya (seperti yang dijabarkan oleh Crowley di atas).

Dalam leksikostatistik, tataran yang berbeda dari subkelompok dinamai sebagai berikut:

Tabel 1

Penamaan Subkelompok Bahasa

\begin{tabular}{ll}
\hline \multicolumn{1}{c}{ Level subkelompok } & \multicolumn{1}{c}{$\begin{array}{c}\text { Persentase Kerabat } \\
\text { pada Kosa Kata } \\
\text { Inti }\end{array}$} \\
\hline Bahasa (language) & $81-100 \%$ \\
Keluarga (family) & $36-81 \%$ \\
Rumpun (stock) & $12-36 \%$ \\
Mikrofilum & $4-12 \%$ \\
Mesofilum & $1-4 \%$ \\
Makrofilum & $0-1 \%$ \\
\hline
\end{tabular}

Dalam klasifikasi leksikostatistik, kesamaan pada tingkat $81-100 \%$ disebut bahasa, kesamaan pada tingkat $36-81 \%$ disebut keluarga, kesamaan pada tingkat $12-36 \%$ disebut rumpun, kesamaan pada tingkat $4-12 \%$ disebut mikrofilum, kesamaan pada tingkat $1-4 \%$ disebut mesofilum, dan kesamaan pada tingkat 0-1\% disebut makrofilum. Namun, perlu dicatat bahwa ahli bahasa yang berbeda adakalanya menggunakan hitungan yang berbeda. Perbandingan yang sistematis memerlukan metode yang tepat. Penelitian ini menggunakan metode perbandingan untuk menyusun perangkat ciri yang berkorespondensi dalam bahasa BK, $\mathrm{BN}$, dan $\mathrm{BS}$ dengan menggunakan daftar kosa kata dasar dari ketiga bahasa itu, yang disusun oleh Morris Swadesh. Daftar kosa kata itu membawa keuntungan dalam penelitian karena terdiri atas kata-kata nonkultural serta retensi kata dasarnya telah diuji dalam bahasa-bahasa yang memiliki naskah-naskah tertulis. 


\section{Tingkat Kekerabatan}

Data sebagaimana terlampir menunjukkan dari 200 kata, kata yang berkognat antara BK dengan BN sebanyak 42 kata, BK dengan BS sebanyak 73 kata, dan BN dengan BS sebanyak 47 kata.

\section{Kekerabatan BK - BN}

Dari dua ratus kosa kata yang diteliti, terdapat 42 kata yang berkerabat antara BK dengan BN. Dengan demikian, dapat dihitung tingkat kekerabatan antara keduanya dengan menggunakan perhitungan leksikostatistik:

Tingkat Kekerabatan:

$\mathrm{C}=$ cognates atau kata yang berkerabat

$\mathrm{K}=$ jumlah kosa kata kerabat

$\mathrm{G}=$ jumlah glos

$$
\begin{aligned}
C & =\underline{\mathrm{K}} \times 100 \% \\
& =\underline{\mathrm{G}} \mathbf{2 0 0} \times 100 \% \\
& =21 \%
\end{aligned}
$$

Dengan menggunakan acuan dari Crowley dan Keraf, kedua bahasa yaitu BM dan BJ berada dalam bahasa serumpun atau family of stock

Untuk menghitung waktu pisah:

$$
\begin{aligned}
& \mathrm{W}=\underline{\log \mathrm{C}} \\
& 2 \log r \\
& \mathrm{~W}=\log 21 / 2 \log 0.805 \\
& =1.561 / 434 \\
& =3,597
\end{aligned}
$$

BK dan BN adalah bahasa yang berkerabat dan berpisah sekitar 3,597 tahun yang lalu atau sekitar tahun 1,578 Sebelum Masehi (dihitung dari tahun 2019). BK dan BN merupakan satu bahasa yang sama sekitar 3,597 tahun yang lalu, sebelum akhirnya berpisah.

\section{Kekerabatan BK - BS}

Dari dua ratus kosa kata yang diteliti, terdapat 73 kata yang berkerabat antara BK dengan BS.

$$
\begin{aligned}
C & =\underline{\mathrm{K}} \times 100 \% \\
& =\frac{73}{200} \times 100 \% \\
& =37 \%
\end{aligned}
$$

Dengan menggunakan acuan dari Crowley dan Keraf, kedua bahasa yaitu BK dan BS berada dalam bahasa sekeluarga atau language of family.

Untuk menghitung waktu pisah:

$$
\begin{aligned}
& \mathrm{W}=\underline{\log C} \\
& 2 \log r \\
& \mathrm{~W}=\log 37 / 2 \log 0.805 \\
&=994 / 434 \\
&=2,290
\end{aligned}
$$

BK dan BS adalah bahasa yang berkerabat dan berpisah sekitar 2,290 tahun yang lalu atau sekitar tahun 271 Sebelum Masehi (dihitung dari tahun 2019). BK dan BS merupakan satu bahasa yang sama sekitar 2,290 tahun yang lalu, sebelum akhirnya berpisah.

\section{Kekerabatan BN - BS}

Dari dua ratus kosa kata yang diteliti, terdapat 47 kata yang berkerabat antara BN dengan BS.

$$
\begin{aligned}
\mathrm{C} & =\underline{\mathrm{K}} \times 100 \% \\
& =\frac{47}{200} \times 100 \% \\
& =24 \%
\end{aligned}
$$

Dengan menggunakan acuan dari Crowley dan Keraf, kedua bahasa yaitu BN dan BS berada dalam bahasa serumpun atau family of stock.

Untuk menghitung waktu pisah:

$$
\begin{aligned}
& \mathrm{W}=\underline{\log \mathrm{C}} \\
& 2 \log \mathrm{r} \\
& \mathrm{W}=\log 24 / 2 \log 0.805 \\
&=1,427 / 434 \\
&=3,288
\end{aligned}
$$


BN dan BS adalah bahasa yang berkerabat dan berpisah sekitar 3,288 tahun yang lalu atau sekitar tahun 1,269 Sebelum Masehi (dihitung dari tahun 2019). BN dan BS merupakan satu bahasa yang sama sekitar 3,288 tahun yang lalu, sebelum akhirnya berpisah.

\section{Simpulan}

Identifikasi terhadap 200 kosakata dasar dalam BK, BN, dan BS menunjukkan bahwa:

1. Tingkat kekerabatan BK dan BN adalah $21 \%$. Kedua bahasa berada dalam satu rumpun atau family of stock.

2. Tingkat kekerabatan BK dan BS adalah $37 \%$. Kedua bahasa berada dalam satu keluarga atau language of family.

3. Tingkat kekerabatan BN dan BS adalah $24 \%$. Kedua bahasa berada dalam satu rumpun atau family of stock.

4.

\section{Daftar Pustaka}

Crowley, Terry dan Claire Bowern. 2010. An Introduction to Historical Linguistics. Oxford: Oxford University Press.
Juliana. 2012. "Kekerabatan Bahasa Batak, Bahasa Nias, dan Bahasa Melayu". Tesis. Medan: Universitas Sumatera Utara.

Juliana. 2013. "Tingkat Kekerabatan Bahasa Mandailing, Bahasa Jawa, dan Bahasa Aceh”. Jurnal Medan Makna, Vol. XI No. 1, 2013: 107-114.

Keraf, G. 1984. Linguistik Bandingan Historis. Jakarta: Gramedia Pustaka Utama.

Kridalaksana, Harimurti. 2008. Kamus Linguistik. Jakarta: PT Gramedia Pustaka Utama.

Mahsun. 1995. Dialektologi Diakronis: Sebuah Pengantar. Yogyakarta: Gadjah Mada University Press.

Mahsun. 2005. Metode Penelitian Bahasa. Jakarta: Raja Grafindo Persada.

Mbete, Aron Meko. 2002. Metode Linguistik Diakronis. Bali: Universitas Udayana.

Widayati, Dwi. 2018. "Hubungan Kekerabatan Bahasa Nias dan Bahasa Sigulai". Jurnal TUTUR Asosiasi Peneliti Bahasa-Bahasa Lokal (APBL), Vol. 4 No. 1 Februari 2018: 1-8.

\section{LAMPIRAN 1}

Daftar Kosa Kata Swadesh Bahasa Karo, Bahasa Nias, dan Bahasa Simalungun

\begin{tabular}{|c|c|c|c|c|c|}
\hline No. & PAN & BK & BN & BS & Glos \\
\hline 1. & * ‘abu & [taneh] & [awu] & [abu kabuk] & abu \\
\hline 2. & * wai & [lau] & [idanə] & [bah] & air \\
\hline 3. & * wakat & [urat] & [wa'a] & [urat] & akar \\
\hline 4. & * 'aliy & [maler] & [ele] & [manorus] & alir \\
\hline 5. & * ana'- & - & [ono] & [niombah] & anak \\
\hline 6. & * aGin & [agin] & [ani] & [logou] & angin \\
\hline 7. & $*$ asu & [biay] & [asu] & [asu] & anjing \\
\hline 8. & * 'apa' & [kai] & [hadia] & [aha] & apa \\
\hline 9. & * apuy & [api] & [alitə] & [apuy] & api \\
\hline 10. & * qasap & [asap] & [simbo] & [timus] & asap \\
\hline 11. & * 'atep & ['atep] & [nawaeta] & [tayub] & atap \\
\hline 12. & $*$ atas & [datas] & [yawa] & [atas] & atas \\
\hline 13. & * avan & [remay] & [lawuo] & [hombun] & awan \\
\hline 14. & $*$ manuk & [manuk] & [manu] & [dayok] & ayam \\
\hline
\end{tabular}




\begin{tabular}{|c|c|c|c|c|c|}
\hline 15. & * ku'a['] & [uga] & [hawaisa] & [naga] & bagaimana \\
\hline 16. & * bagey & [bagey'] & [be'əma] & [bag] & bagi \\
\hline 17. & $*$ muacuNu & [tutuy] & [lacunu] & [tutuy] & bakar \\
\hline 18. & * ‘ama' & [bapa] & [ama] & [aman] & bapak \\
\hline 19. & * ‘in $\mid \mathrm{p}$ & [medem] & [labilaə] & - & baring \\
\hline 20. & * bayu & [mbaru] & [awena] & [baru] & baru \\
\hline 21. & * basəq & [bencah] & [abasə] & [bossot] / [arbah] & basah \\
\hline 22. & * bataG & [batan] & [dəla] & [batan] & batang \\
\hline 23. & * batu' & [batu] & [batu] & [batu] & batu \\
\hline 24. & * babah & [bawah] & [to'u] & [toruh] & bawah \\
\hline 25. & * buhat & [dahin] & [mohaləwə] & [marhorja] & bekerja \\
\hline 26. & $* \mathrm{~b} \mid \mathrm{lah}$ & [naka] & [sila] & [bolah] / [batis] & belah \\
\hline 27. & $*$ beli & [tukur] & [əli] & [boli] & beli \\
\hline 28. & * putaR & [pute/r/] & [futa] & [husor] & belok \\
\hline 29. & $*$ bener & [tuhu] & $\begin{array}{l}{[\operatorname{sindruhu}] /[\text { ot }} \\
\text { ulə] }\end{array}$ & [bonar] /[pintor] & benar \\
\hline 30. & $*$ b|ndul & [beykak] & [asila] / [abao] & [basol]/[burnay] & bengkak \\
\hline 31. & * beRat & [mberat] & [abua] & [borat] & berat \\
\hline 32. & $*$ diri & [cinder] & [mosindro] & [jonjon] & berdiri \\
\hline 33. & * besa/r/ & [galay] & [ebua] & [bayar] & besar \\
\hline 34. & * bintaG & [bintan] & [ndrəfi] & [bintan] & bintang \\
\hline 35. & $*$ bisul & [bisul] & [təgidoyo] & [bayoh] & bisul \\
\hline 36. & * bu'ah & [erbuah] & [mbua] & [buah] & buah \\
\hline 37. & * buka' & [buka] & [bokai] & [buha] & buka \\
\hline 38. & * kawakə & [bulan] & [bawa] & [bulan] & bulan \\
\hline 39. & * bulu' & [mbulu'] & [bu'lu] & [ambulu] & bulu \\
\hline 40. & * buya' & [rudan] & [buya] & [buna] & bunga \\
\hline 41. & * bunuh & [bunoh] & $\begin{array}{l}\text { [mamunu] } \\
\text { [bunu] }\end{array}$ & [mamunuh] & bunuh \\
\hline 42. & $*$ buru & [buru] & $\begin{array}{l}\text { [mohandro]/ } \\
\text { [mameasu] }\end{array}$ & [ayak] & buru \\
\hline 43. & $*$ buruN & [perik] & {$[$ fofo $] /[$ manu $]$} & [manuk-manuk] & burung \\
\hline 44. & * bayuk & [macik] & [obou] & [basou] & busuk \\
\hline 45. & * caciN & [gaya] & [norio] & [sasin] & cacing \\
\hline 46. & * ciyum & [aygeh] & $\begin{array}{l}\text { [la'ago] } \\
\text { [uma] }\end{array}$ & [angoh] & cium \\
\hline 47. & * maliG & [nayko] & [managə] & [takko] & curi \\
\hline 48. & $*$ dagiG & [jukut] & [nagole] & [jagal] & daging \\
\hline 49. & * dalem & [bagas] & {$\left[\mathrm{bak}^{\mathrm{h}} \mathrm{a}\right]$} & [ibagas] & dalam \\
\hline 50. & $*$ den & [den] & [fauma] & [anjaha] & dan, dengan \\
\hline 51. & * danaw & [danaw] & [nidanə sebua] & [tao] & danau \\
\hline 52. & * dayah & [dareh] & [ndro] / [do] & [daroh] & darah \\
\hline 53. & $*$ dataG & [reh] & [so] & [roh] & datang \\
\hline 54. & * da'un & [buluy] & [bulu] & [bulun] & daun \\
\hline 55. & * dabuk & [debu] & [gawu-gawu] & [horbuk] & debu \\
\hline 56. & $*$ rojo & [mbegi] & [royo] & [bogei] & dengar \\
\hline 57. & $* \mathrm{di}$ & [i] & {$[\mathrm{ba}] /\left[\mathrm{k}^{\mathrm{h}} \mathrm{e}\right]$} & [i] & di \\
\hline
\end{tabular}




\begin{tabular}{|c|c|c|c|c|c|}
\hline 58. & $*-\mathrm{n}, \mathrm{a}$ & {$[-n, a]$} & $\begin{array}{l}\text { [yaia } \\
\text { matua] }\end{array}$ & [dalahi] & dia \\
\hline 59. & $* \mathrm{i}(\mathrm{nn}) \mathrm{u}$ & [ija] & [he'eso] & [ija] & dimana \\
\hline 60. & $*$ diGin & [digin] & [oafu] & [torsuk] & dingin \\
\hline 61. & * duwa & [duwa] & [dombua] & [dua] & dua \\
\hline 62. & $*$ dukduk & [kundul] & [moda-dao] & [hundul] & duduk \\
\hline 63. & * 'ikuy & ['ikur] & [gio] & [ihur] & ekor \\
\hline 64. & * opat & [empat] & [əfa] & [opat] & empat \\
\hline 65. & $*$ kaw & [enko] & [yau'gə] & [handian] & engkau, \\
\hline 66. & * kali' & [gali] & {$\left[\mathrm{k}^{\mathrm{h}} \mathrm{ao}\right]$} & [bahar] / [hurak] & gali \\
\hline 67. & $* \operatorname{asin}$ & [sira] & [asio] & [garam] & garam \\
\hline 68. & * garut & [gergo] & [okawi] & [garut] & garuk \\
\hline 69. & * ipən & [ipən] & [ifə] & [ipon] & gigi \\
\hline 70. & $* \mathrm{kaPu}$ & [karat] & [usu] & [harat] / [roprop] & gigit \\
\hline 71. & * gu(n)duh & [gu(n)duh] & [ug-ugu] & [loygur] & guntur \\
\hline 72. & * waRih & [warih] & [hari] & [ari] & hari \\
\hline 73. & * Pate & [ukur] & [ate] & [atei] & hati \\
\hline 74. & $*$ isu & [igun] & {$\left[\mathrm{ik}^{\mathrm{h}} \mathrm{u}\right]$} & [igun] & hidung \\
\hline 75. & * hudip & [geluh] & [fauri] / [auri] & [goluh] & hidup \\
\hline 76. & * gizau & [meratah] & [owuruge'e] & [ratah] & hijau \\
\hline 77. & * sepsep & [sirup] & [jiji'o] & [osop] & hisap \\
\hline 78. & * $\mathrm{i}(\mathrm{n}) \mathrm{t} \mid \mathrm{m}$ & [mbirin] & [ailə] & [biron] & hitam \\
\hline 79. & * kira & [kira] & [erai] & [tira] & hitung \\
\hline 80. & * hujan & [udan] & [deu] & [udan] & hujan \\
\hline 81. & * utan & [karayen] & [gawa] & [harayan] & hutan \\
\hline 82. & * 'ina' & [nande] & [ina] & [inay] & ibu \\
\hline 83. & * I'a & [ikan] & [i'a] & [deyke] / [ihan] & ikan \\
\hline 84. & $* \mathrm{iket}$ & [iket] & [əbə-bə] & [arit] / [rahut] & ikat \\
\hline 85. & $*$ ini & [ini] & [yae] & [on] & ini \\
\hline 86. & * binay & [isteri] & $\begin{array}{l}\text { [dona } \\
\text { ira'alawe] }\end{array}$ & [binuat] & istri \\
\hline 87. & $* \mathrm{itu}(\mathrm{h})$ & [ah] & [yawə’i] & [ai] / [in] & itu \\
\hline 88. & * jahat & [jahat] & [amui] & [junkat] & jahat \\
\hline 89. & $*$ jahit & [enjarum] & {$[\operatorname{tagu}] /[\mathrm{afu}]$} & [jait] & jahit \\
\hline 90. & * dalan & [dalan] & [mofanə] & [dalan] & jalan \\
\hline 91. & $*$ janji & [janji] & [lafabu'u] & $\begin{array}{l}\text { [padan] / [bagah] / } \\
\text { [buhul] }\end{array}$ & janji \\
\hline 92. & $*$ zantuN & [pusuh] & [tədə] & [pusu-pusu] & jantung \\
\hline 93. & * zaRum & [zarum] & [atarə] & [jarum] & jarum \\
\hline 94. & * labuh & [dabuh] & [alabu] & [dabuh] & jatuh \\
\hline 95. & * jawuh & [ndaoh] & [arəu] & [daoh] & jauh \\
\hline 96. & * kabut & [remay] & [ləoroma] & [ombun] & kabut \\
\hline 97. & * waqe & [nahe] & [gahe] & [haes] & kaki \\
\hline 98. & * kambiN & [kambin] & [nambi] & [hambin] & kambing \\
\hline 99. & * wanan & [kemuhen] & [gambələ] & [siamun var sihamun] & kanan \\
\hline 100. & * ija $(\mathrm{nN})$ & {$[\mathrm{ija}(\mathrm{Nn})]$} & [hamega] & $\begin{array}{l}\text { [andigan] / } \\
\text { [antigan] / [nandigan] }\end{array}$ & kapan \\
\hline
\end{tabular}




\begin{tabular}{|c|c|c|c|c|c|}
\hline 101. & * hucap & [hucap] & [niwai] & [marhata] & kata \\
\hline 102. & * kəu & [kayu'] & [e'u] & [hayu] & kayu \\
\hline 103. & * kulambu & [kulambu] & [gulambu] & [hulambu] & kelambu \\
\hline 104. & $*$ ulu & [takal] & [həgə] & [ulu] & kepala \\
\hline 105. & * keRin & [kerin] & [acufo] & [hian] & kering \\
\hline 106. & $* \operatorname{tuk}(\mathrm{tuk})$ & [ketuk] & [ətoko] & [dungar] / [doltuk] & ketuk \\
\hline 107. & $*$ kilap & [kilap] & [molina-lina] & [marhilo] & kilat \\
\hline 108. & * wiri & [kawes] & [gambera] & [siambilou] & kiri \\
\hline 109. & $*$ kita & [ita] & [ya'aga] & [hanami] & kita \\
\hline 110. & $*$ labu & [melket] & [taunə] & [butak] & kotor \\
\hline 111. & * kuli & [kulin] & [guli-uli] & [kulit] & kulit \\
\hline 112. & * kuniG & [kunin] & [ausə] & [gorsin] & kuning \\
\hline 113. & * kunaq & [kunyah] & [mamio-mio] & [hil-hil] & kunyah \\
\hline 114. & * utu & [kutu] & [utu] & [hutu] & kutu \\
\hline 115. & * lawa(lawa) & $\begin{array}{l}\text { [lawa- } \\
\text { lawa] }\end{array}$ & [lawa-lawa] & - & laba-laba \\
\hline 116. & * lain & [lain] & [tanəbə’ə] & [pandur] & lain \\
\hline 117. & * laki & [dilaki] & [iramatua] & [dalahi] & laki-laki \\
\hline 118. & $*$ laGit & [lanit] & [banu] & [lanit] & langit \\
\hline 119. & * la'ud & [laut] & [dalu nasi] & - & laut \\
\hline 120. & $*$ bi(n)daG & [galan] & [ebolo] & [tahar] & lebar \\
\hline 121. & * lihiy & [leher] & [bagi] & [borgok] & leher \\
\hline 122. & * lila- & [dilah] & [lela] & [dilah] & lidah \\
\hline 123. & * teGuk & [nen] & [faigi] & [didah] & lihat \\
\hline 124. & *lima & [lima] & [lima] & [lima] & lima \\
\hline 125. & * lompit & [lipat] & [fatə’ə] & $\begin{array}{l}\text { [loppit] / [lulun] / } \\
\text { [sorpih] }\end{array}$ & lipat \\
\hline 126. & * ludah & [cidur] & [ilo] & [tijur] & ludah \\
\hline 127. & * paya & {$[\mathrm{man}]$} & [mana] & [mayan] & makan \\
\hline 128. & * malem & [berngi] & [boni] & [bornin] & malam \\
\hline 129. & $*$ malu & [malu] & [aila] & $\begin{array}{l}\text { [maila] / [bador]/ [ela] } \\
\text { / [ila] }\end{array}$ & malu \\
\hline 130. & $*$ mata & [mata] & [hərə] & [londar] & mata \\
\hline 131. & $*$ mate & [mate] & [mate] & [mate] & mati \\
\hline 132. & * huwap & [meyuap] & [meha] & [marhoyam] & menguap \\
\hline 133. & * meRa & [megara] & [oyo] & [gerger] & merah \\
\hline 134. & $* \operatorname{tu}(\mathrm{O}, \mathrm{q}) \mathrm{a}$ & [kalak-ah] & [yaira] & [nasida] & mereka \\
\hline 135. & $*\left[{ }^{\prime}\right] \mathrm{i}(\mathrm{m}) \mathrm{pi}$ & ['impi] & [manifi] & [nipi] & mimpi \\
\hline 136. & * Inu & ['inem] & [inu $]$ & [inum] & minum \\
\hline 137. & $*$ miri & [mirin] & [manaere] & [seder] & miring \\
\hline 138. & * baba- & [babah] & [bawa] & [babah] & mulut \\
\hline 139. & $*$ muta & [muta] & [mouta] & [utah] & muntah \\
\hline 140. & * na ava & [kepas] & [hanu-hanu] & [hosah] & nafas \\
\hline 141. & * naik & [naykih] & [aeyawa] & [takkog] & naik \\
\hline 142. & $*$ gelar & [gelar] & [dəi] & [goran] & nama \\
\hline 143. & * namuk & [namok] & [ndi-ndi] & [ronit] & nyamuk \\
\hline 144. & * ‘uyaG & [jelma] & [niha] & [halak] & orang \\
\hline
\end{tabular}




\begin{tabular}{|c|c|c|c|c|c|}
\hline 145. & * panas & [melas] & {$\left[\operatorname{auk}^{\mathrm{h}} \mathrm{u}\right]$} & [milas] / [hayar] & panas \\
\hline 146. & * pand'aG & [geday] & [anau] & [goday] & panjang \\
\hline 147. & $*$ kesik & [kersik] & [gawu-gawu] & [tiga] & pasir \\
\hline 148. & $*$ dada & [dada] & [dətəa] & [tonton] & payudara \\
\hline 149. & * pegaG & [jemak] & $\begin{array}{l}\text { [otaha] } \\
\text { [malohe] }\end{array}$ & $\begin{array}{l}\text { [jolom] / [golom] / } \\
\text { [gomak] / [jamah] }\end{array}$ & pegang \\
\hline 150. & * pandak & [gendek] & [adogo] & $\begin{array}{l}\text { [pondok] / [getek] / } \\
\text { [pondal] }\end{array}$ & pendek \\
\hline 151. & $*(\mathrm{k} . \mathrm{g})$ emes & [pareh] & [fulə’ə] & [poroh] & peras \\
\hline 152. & * daRa & [diberu] & [ira'alawe] & [naboru] & perempuan \\
\hline 153. & $*(\mathrm{t}) \mathrm{ijan}$ & [beltek] & [betua] & [boltok] & perut \\
\hline 154. & ${ }^{*} \mathrm{kI}(\mathrm{r}) \mathrm{a}$ & [rukor] & [manera-yera] & [marpikir] & pikir \\
\hline 155. & $*$ fill & [pilih] & [fili] & [pilih] & pilih \\
\hline 156. & * keRat & [keret] & [taba] & [obog] & potong \\
\hline 157. & $*$ pu(G)kul & [pekpek] & [bəji] & 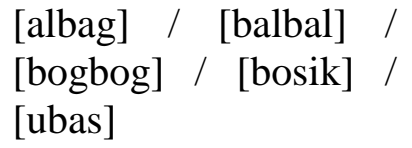 & pukul \\
\hline 158. & $*$ putih & [mbentar] & [afusi] & [bontar] & putih \\
\hline 159. & * bulu' & [rambut] & [bu] & [jambulan] & rambut \\
\hline 160. & * laGuj & [erkenen] & [molani] & [marlaywe] & renang \\
\hline 161. & * yumah & [rumah] & [omo] & [jabu] & rumah \\
\hline 162. & * rumput & [peren] & [ndru'u] & [duhut] & rumput \\
\hline 163. & $*$ məsaki(t) & [sakit] & [mofək $\left.\mathrm{k}^{\mathrm{h}} \partial\right]$ & $\begin{array}{l}\text { [boritan] / [baygar] / } \\
\text { [borit] }\end{array}$ & sakit \\
\hline 164. & $*$ sa & [sada] & [sa ambua] & [sada] & satu \\
\hline 165. & * 'aku' & [aku] & [yaodo] & [ahu] & saya \\
\hline 166. & * kapak & [kaben] & [gəfi] & [naboy] & sayap \\
\hline 167. & * buni' & [buni] & [binio] & [marponop] / [buni] & sembunyi \\
\hline 168. & ${ }^{*}$ se(m)pit & [picet] & [aləjə] & [pusok] & sempit \\
\hline 169. & * (')abih & [kerina] & [fefu] & [nagori] & semua \\
\hline 170. & * sai' & [ise] & [haniha] & [ise] & siapa \\
\hline 171. & * laki' & [dilaki] & [doya] & [pargoton] & suami \\
\hline 172. & * tahu' & [tahu] & [uila] & [ibotoh] & tahu \\
\hline 173. & * tahun & [tahun] & [ndrəfi] & [tahun] & tahun \\
\hline 174. & $*$ tazem & [entelap] & [atarə] & [arot] & tajam \\
\hline 175. & * ma-taku & [mbiar] & [ata'u] & [biar] & takut \\
\hline 176. & * tali' & [nali] & [dali] & [tali] & tali \\
\hline 177. & $*$ tanəh & [taneh] & [tanə] & [tanoh] & tanah \\
\hline 178. & $*$ tanəm & [tanam] & [mananə] & [kubur] & tanam \\
\hline 179. & $*$ taGan & {$[\tan ]$} & [daya] & [tayan] & tangan \\
\hline 180. & $*$ taGis & [yandon] & [fe'e] & [tanis] & tangis \\
\hline 181. & $* \mathrm{t}|\mathrm{b}| 1$ & [mekapal] & [awe'e-we'e] & [andal] & tebal \\
\hline 182. & * taliGa' & [cupin] & [fiso] & [pingol] & telinga \\
\hline 183. & $*$ telur & [naroh] & [adulo] & [tolur] & telur \\
\hline 184. & * tembak & [tebak] & [fana] & [remay] & tembak \\
\hline 185. & * layaG & [kabay] & [humombo] & [habay] & terbang \\
\hline 186. & * tawa & [tawa] & [mailai] & [tertawa] & tertawa \\
\hline
\end{tabular}




\begin{tabular}{|c|c|c|c|c|c|c|}
\hline 187. & $*$ tidur & [medem] & [mərə] & & [modom] & tidur \\
\hline 188. & * telu' & [telu] & [təlu] & & [tolu] & tiga \\
\hline 189. & $*(\mathrm{t}) \mathrm{ikam}$ & [nebak] & [cufo] & & [tobak] & tikam \\
\hline 190. & $*$ tikus & [tikus] & [te'u] & & [ubag] / [ubagikus] & tikus \\
\hline 191. & * timuy & [timur] & [mbanu] & & $\begin{array}{l}\text { [hapoltakan]/ } \\
\text { [habinsaran] }\end{array}$ & timur \\
\hline 192. & $*$ manifi & [menipes] & [anifi-nifi] & & [rampis] & tipis \\
\hline 193. & $*$ tiyup & [embus] & [hawusi] & & [ombus] & tiup \\
\hline 194. & * ma-tua & [tua] & [atua] & & [tua] & tua \\
\hline 195. & * fitu & [pitu] & [fitu $]$ & & [pitu] & tujuh \\
\hline 196. & $*$ (n)tula & [tulan] & [təla] & & [barin-barin] & tulang \\
\hline 197. & $*$ tu(m)buh & [tumbuh] & [manəi] & & - & tumbuh \\
\hline 198. & $*$ but $\mid \mathrm{k}$ & [metultul] & $\begin{array}{l}\text { [loatarə] } \\
\text { [afuru] }\end{array}$ & l & [majol] & tumpul \\
\hline 199. & * nipa & [nipe] & [ulə] & & [ulog] & ular \\
\hline 200. & $*^{*}$ bi(t)uka(') & [tuka] & [ri'i-ri'i] & & [bituha] & usus \\
\hline
\end{tabular}


LAMPIRAN 2

Data Kognat Bahasa Karo, Bahasa Nias, dan Bahasa Simalungun

\begin{tabular}{|c|c|c|c|}
\hline No. & BK & BN & BS \\
\hline 1. & $\mathrm{~A}$ & $\mathrm{~B}$ & $\mathrm{C}$ \\
\hline 2. & A & B & $\mathrm{C}$ \\
\hline 3. & A & B & A \\
\hline 4. & A & A & B \\
\hline 5. & - & [ono] & [niombah] \\
\hline 6. & A & A & B \\
\hline 7. & A & B & B \\
\hline 8. & $\mathrm{~A}$ & B & $\mathrm{C}$ \\
\hline 9. & A & B & $\mathrm{C}$ \\
\hline 10. & A & B & $\mathrm{C}$ \\
\hline 11. & A & B & $\mathrm{C}$ \\
\hline 12. & A & B & A \\
\hline 13. & A & B & $\mathrm{C}$ \\
\hline 14. & A & A & B \\
\hline 15. & A & B & A \\
\hline 16. & A & B & A \\
\hline 17. & A & B & A \\
\hline 18. & A & B & B \\
\hline 19. & [medem] & [labilaə] & - \\
\hline 20. & A & B & $\mathrm{C}$ \\
\hline 21. & A & B & $\mathrm{C}$ \\
\hline 22. & A & B & A \\
\hline 23. & A & $\mathrm{A}$ & A \\
\hline 24. & A & B & B \\
\hline 25. & $\mathrm{~A}$ & B & $\mathrm{C}$ \\
\hline 26. & A & B & $\mathrm{C}$ \\
\hline 27. & A & B & B \\
\hline 28. & A & B & $\mathrm{C}$ \\
\hline 29. & $\mathrm{~A}$ & B & $\mathrm{C}$ \\
\hline 30. & A & B & $\mathrm{C}$ \\
\hline 31. & A & B & A \\
\hline 32. & A & B & $\mathrm{C}$ \\
\hline 33. & A & B & $\mathrm{C}$ \\
\hline 34. & A & B & A \\
\hline 35. & A & B & $\mathrm{C}$ \\
\hline 36. & A & A & A \\
\hline 37. & A & B & A \\
\hline 38. & A & B & A \\
\hline 39. & A & A & A \\
\hline 40. & A & B & B \\
\hline 41. & $\mathrm{~A}$ & B & B \\
\hline
\end{tabular}


42. A

43. A

44. A

45. A

$\begin{array}{ll}46 . & \mathrm{A} \\ \text { 47. } \mathrm{A}\end{array}$

48. A

$49 . \quad \mathrm{A}$

50. A

51. A

52. A

53. A

55. A

$\begin{array}{ll}56 . & \text { A } \\ 57 . & \text { A }\end{array}$

58. A

59. A

60. A

61. A

62.

63.

64. A

65. A

66. A

67. A

68. A

69. A

70. A

71. A

72. A

73. A

$\begin{array}{ll}74 . & \mathrm{A} \\ \text { 75. } & \mathrm{A}\end{array}$

76. A

77. A

$\begin{array}{ll}78 . & \mathrm{A} \\ 79 . & \mathrm{A}\end{array}$

80. A

81. A

82. A

83. A

84. A

85. A

86. A

87. A

88. A

$\begin{array}{ll}\text { B } & \text { C } \\ \text { B } & \text { B } \\ \text { B } & \text { C } \\ \text { B } & \text { C }\end{array}$

A

A

C

A

C

C

A

A

A

C

A

A

C

A

A

A A C C B C A A B A B A A A C A A A A B A C C C C C 


\begin{tabular}{|c|c|c|c|}
\hline 89. & $\mathrm{~A}$ & B & $\mathrm{C}$ \\
\hline 90. & A & $\mathrm{B}$ & A \\
\hline 91. & A & B & $\mathrm{C}$ \\
\hline 92. & A & $\mathrm{B}$ & $\mathrm{A}$ \\
\hline 93. & A & $\mathrm{B}$ & $\mathrm{A}$ \\
\hline 94. & A & A & A \\
\hline 95. & A & B & $\mathrm{A}$ \\
\hline 96. & A & $\mathrm{B}$ & $\mathrm{C}$ \\
\hline 97. & A & A & A \\
\hline 98. & A & A & A \\
\hline 99. & A & $\mathrm{B}$ & $\mathrm{C}$ \\
\hline 100. & A & $\mathrm{B}$ & $\mathrm{C}$ \\
\hline 101. & A & $\mathrm{B}$ & $\mathrm{C}$ \\
\hline 102. & A & A & A \\
\hline 103. & A & A & A \\
\hline 104. & A & B & $\mathrm{C}$ \\
\hline 105. & A & $\mathrm{B}$ & $\mathrm{C}$ \\
\hline 106. & A & $\mathrm{B}$ & $\mathrm{C}$ \\
\hline 107. & A & $\mathrm{B}$ & $\mathrm{C}$ \\
\hline 108. & A & $\mathrm{B}$ & $\mathrm{C}$ \\
\hline 109. & $\mathrm{~A}$ & $\mathrm{~B}$ & $\mathrm{C}$ \\
\hline 110. & A & $\mathrm{B}$ & $\mathrm{C}$ \\
\hline 111. & A & A & A \\
\hline 112. & $\mathrm{~A}$ & B & $\mathrm{C}$ \\
\hline 113. & $\mathrm{~A}$ & $\mathrm{~B}$ & $\mathrm{C}$ \\
\hline 114. & A & A & A \\
\hline 115. & $\begin{array}{l}\text { [lawa- } \\
\text { lawa] }\end{array}$ & [lawa-lawa] & - \\
\hline 116. & A & B & $\mathrm{C}$ \\
\hline 117. & A & $\mathrm{B}$ & A \\
\hline 118. & A & $\mathrm{B}$ & A \\
\hline 119. & [laut] & [dalu nasi] & - \\
\hline 120. & A & $\mathrm{B}$ & $\mathrm{C}$ \\
\hline 121. & A & B & $\mathrm{C}$ \\
\hline 122. & A & B & A \\
\hline 123. & A & B & $\mathrm{C}$ \\
\hline 124. & A & A & A \\
\hline 125. & A & B & $\mathrm{C}$ \\
\hline 126. & A & B & A \\
\hline 127. & A & A & A \\
\hline 128. & A & A & A \\
\hline 129. & A & B & B \\
\hline 130. & A & B & $\mathrm{C}$ \\
\hline 131. & A & A & A \\
\hline 132. & A & B & $\mathrm{C}$ \\
\hline 133. & A & B & $\mathrm{C}$ \\
\hline 134. & A & B & $\mathrm{C}$ \\
\hline
\end{tabular}




\begin{tabular}{|c|c|c|c|}
\hline 135. & A & A & A \\
\hline 136. & A & A & A \\
\hline 137. & A & B & C \\
\hline 138. & A & A & A \\
\hline 139. & A & A & A \\
\hline 140. & A & B & C \\
\hline 141. & A & B & $\mathrm{C}$ \\
\hline 142. & A & B & C \\
\hline 143. & A & B & C \\
\hline 144. & A & B & C \\
\hline 145. & A & B & A \\
\hline 146. & A & B & A \\
\hline 147. & A & B & C \\
\hline 148. & A & B & C \\
\hline 149. & A & B & $\mathrm{C}$ \\
\hline 150. & A & B & C \\
\hline 151. & A & B & A \\
\hline 152. & A & B & $\mathrm{C}$ \\
\hline 153. & A & A & A \\
\hline 154. & A & B & C \\
\hline 155. & A & B & A \\
\hline 156. & A & B & C \\
\hline 157. & A & B & C \\
\hline & A & B & A \\
\hline 159. & A & B & C \\
\hline 160. & A & B & $\mathrm{C}$ \\
\hline 161. & A & B & C \\
\hline 162. & A & B & C \\
\hline 163. & A & B & C \\
\hline 164. & A & A & A \\
\hline 165. & A & B & A \\
\hline 166. & A & B & C \\
\hline 167. & A & A & A \\
\hline 168. & A & B & C \\
\hline 169. & A & B & C \\
\hline 170. & A & B & A \\
\hline 171. & A & B & C \\
\hline 172. & A & B & C \\
\hline 173. & A & B & C \\
\hline 174. & A & B & C \\
\hline 175. & A & B & A \\
\hline 176. & A & A & A \\
\hline 177. & A & A & A \\
\hline 178. & A & A & B \\
\hline 179. & A & A & A \\
\hline 180. & A & B & C \\
\hline 181. & A & B & C \\
\hline
\end{tabular}




\begin{tabular}{|c|c|c|c|}
\hline 182. & A & B & $\mathrm{C}$ \\
\hline 183. & A & B & $\mathrm{C}$ \\
\hline 184. & A & B & $\mathrm{C}$ \\
\hline 185. & $\mathrm{~A}$ & B & A \\
\hline 186. & A & B & $\mathrm{C}$ \\
\hline 187. & A & A & A \\
\hline 188. & A & A & A \\
\hline 189. & A & B & A \\
\hline 190. & A & A & A \\
\hline 191. & A & B & $\mathrm{C}$ \\
\hline 192. & A & B & $\mathrm{C}$ \\
\hline 193. & A & A & A \\
\hline 194. & A & A & A \\
\hline 195. & A & A & A \\
\hline 196. & A & A & B \\
\hline 197. & [tumbuh] & [manəi] & - \\
\hline 198. & A & B & $\mathrm{C}$ \\
\hline 199. & A & B & B \\
\hline 200. & A & $\mathrm{B}$ & $\mathrm{C}$ \\
\hline
\end{tabular}

Keterangan data Lampiran 1 dan Lampiran 2:

Kolom 1: no urut daftar kosa kata dasar Swadesh.

Kolom 2: Proto-Austronesia

Kolom 3: Bahasa Karo (BK)

Kolom 4: Bahasa Nias (BN)

Kolom 5: Bahasa Simalungun (BS)

Kolom 6: glos bahasa acuan dalam Bahasa Indonesia

Huruf A: melambangkan kata yang berkognat, dengan bahasa yang ada di kolom ketigs sebagai acuan (dalam hal ini bahasa Karo)

Huruf B: melambangkan kata yang tidak berkognat dengan bahasa Karo, dengan bahasa Nias sebagai acuan.

Huruf C: melambangkan kata tidak berkognat dengan bahasa Karo dan bahasa Nias, dengan bahasa Simalungun sebagai bahasa acuan. 